US Army Corps

of Engineers $S_{\circledast}$

Engineer Research and

Development Center

Ecosystem Management and Restoration Research Program

Formulation of a Multi-Scale Watershed Ecological Model Using a Statistical Approach

Bruce A. Pruitt, K. Jack Killgore, W. Todd Slack,

November 2020

and Ramune Matuliauskaite 
The US Army Engineer Research and Development Center (ERDC) solves the nation's toughest engineering and environmental challenges. ERDC develops innovative solutions in civil and military engineering, geospatial sciences, water resources, and environmental sciences for the Army, the Department of Defense, civilian agencies, and our nation's public good. Find out more at www.erdc.usace.army.mil.

To search for other technical reports published by ERDC, visit the ERDC online library at https://erdclibrary.on.worldcat.org/discovery. 


\title{
Formulation of a Multi-Scale Watershed Ecological Model Using a Statistical Approach
}

\author{
Bruce A. Pruitt \\ Environmental Laboratory \\ US Army Engineer Research and Development Center \\ 960 College Station Road \\ Athens, GA 30605 \\ K. Jack Killgore and W. Todd Slack \\ Environmental Laboratory \\ US Army Engineer Research and Development Center \\ 3909 Halls Ferry Road \\ Vicksburg, MS 39180-6199 \\ Ramune Matuliauskaite \\ US Army Corps of Engineers \\ Nashville District, Project Planning Branch \\ 110 9th Avenue South \\ Nashville, TN 37203
}

Final report

Approved for public release; distribution is unlimited.

Prepared for USACE Nashville District, Project Planning Branch, Nashville, TN 37203

Under Project Number 331898, “Duck \& Buffalo River Watershed Assessment” 


\section{Abstract}

The purpose of this special report is to provide a statistical stepwise process for formulation of ecological models for application at multiple scales using a stream condition index (SCI). Given the global variability of aquatic ecosystems, this guidance is for broad application and may require modification to suit specific watersheds or stream reaches. However, the general statistical treatise provided herein applies across physiographies and at multiple scales. The Duck River Watershed Assessment in Tennessee was used, in part, to develop and test this multiscale, statistical approach; thus, it is considered a case example and referenced throughout this report. The findings of this study can be utilized to (1) prioritize watersheds for restoration, enhancement, and conservation; (2) plan and conduct site-specific, intensive ecosystem studies; and (3) assess ecosystem outcomes (that is, ecological lift) applicable to future with and without restoration actions including alternative, feasibility, and cost-benefit analyses and adaptive management.

DISCLAIMER: The contents of this report are not to be used for advertising, publication, or promotional purposes. Citation of trade names does not constitute an official endorsement or approval of the use of such commercial products. All product names and trademarks cited are the property of their respective owners. The findings of this report are not to be construed as an official Department of the Army position unless so designated by other authorized documents. 


\section{Contents}

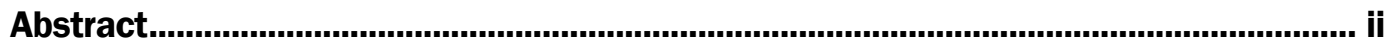

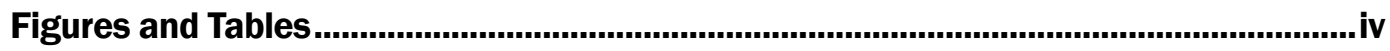

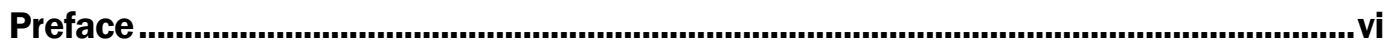

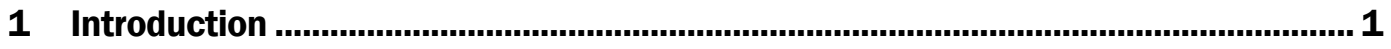

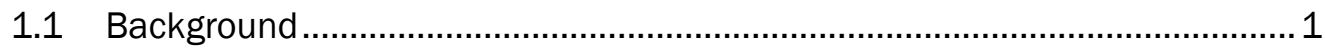

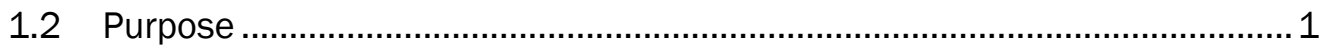

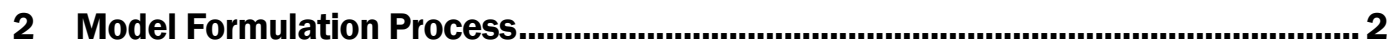

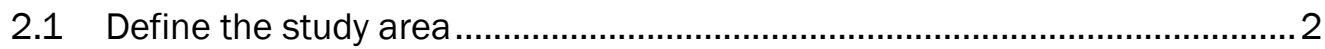

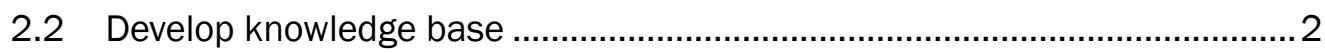

2.3 Stratify by ecoregions and watersheds ..................................................... 5

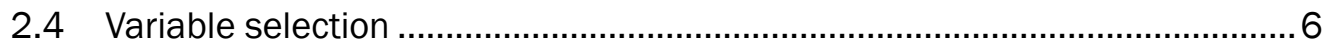

2.5 Formulate Stream Condition Index (SCl) ................................................... 8

2.6 Identify attainable reference conditions ................................................... 13

2.7 Stream condition and aquatic biota correspondence .................................16

2.8 Model validation .................................................................................... 16

2.9 Application of Stream Condition Index ............................................... 18

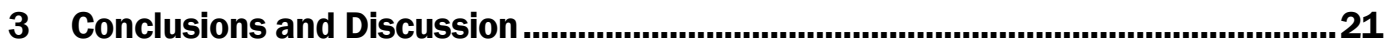

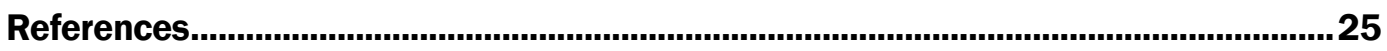

Appendix: Stream Condition Index (SCI) Variable Definitions and Scores .....................28

Report Documentation Page 


\section{Figures and Tables}

\section{Figures}

Figure 1. Model formulation process. Phase 1: Classification and testing; Phase 2: synthesis and application...

Figure 2. Tennessee Level IV Ecoregions depicting Duck River Watershed (demarcated in red) The study area included four Level 4 Ecoregions: Western Highland Rim (71f), Eastern Highland Rim (71g), Outer Nashville Basin (71h) and Inner Nashville Basin (71i).

Figure 3. Level IV Ecoregions and HUC10 watersheds depicting fish Index of Biotic Integrity (IBI) stations by ratings.

Figure 4. Stream condition index (SCl) scaled against environmental disturbance gradient (adapted from Pruitt et al. 2012). Twenty-three percent of the Duck watershed is considered "minimally disturbed to relatively undisturbed", $44 \%$ is "minor disturbance to biotic and abiotic attributes", and $32 \%$ is "major or severe disturbance to biotic and abiotic attributes."

Figure 5. Nonmetric multidimensional scaling on fish IBI data across Level IV Ecoregions, Duck River watershed, Tennessee. Biotic metrics were higher in the Western Highland Rim ecoregion, moderate in the Inner Nashville Basin, variable in the Outer Nashville Basin, and consistently lower in the Eastern Highland Rim. Changes in the biotic metrics can be compared to descriptions of anthropogenic development in the Ecoregions as an approach to evaluate baseline conditions.

Figure 6. Nonmetric multidimensional scaling ordinations of fish species among sites. Symbols represent IBI rating of each site. Vectors identify the direction and strength of correlations. The boxes summarize quadrat characteristics. Analysis indicates that $\mathrm{IBI}$ and $\mathrm{SCl}$ scores decrease due to anthropogenic disturbances and can identify restoration projects that increase biotic diversity.

Figure 7. Estimate of the 90th quantile regression equation with $95 \%$ confidence limits for Stream Condition Index (normalized to 0-1) as a function of the IBI.

Figure 8. SCl scores per HUC12 watersheds, Duck River watershed, Tennessee. By comparing figures 4 and 8,20 of the 87 watersheds experienced "major or severe disturbance to biotic and abiotic attributes" $(\mathrm{SCl}<0.2)$. Thirty-nine of the 87 watersheds experienced "minor disturbance to biotic and abiotic attributes" (SCl 0.2-0.6), and 28 of the 87 watersheds experienced "minimally disturbed to relatively undisturbed" $(\mathrm{SCl}>0.6)$.

Figure 9. Estimate of the 90th regression quantile equation for $\mathrm{SCl}$ (normalized to $0-1$ ) as a function of total developed land. The equation was used to predict $\mathrm{SCl}$ scores for HUCs without monitoring data but with estimates of total developed land.

\section{Tables}

Table 1. Linear regression analysis, $T$-test, $p$-values, correspond with correlations presented in table 7 (highlighted values are significant at $p<0.01$ and coincide with the correlations in table 2). 
Table 2. Correlation product matrix on stream variables, significant correlations for positive and negative relationships highlighted green and magenta, respectively.

Table 3. Direct and indirect correlations between model variables (variables as above; embeddedness [EMB], emphasized). 


\section{Preface}

This study was conducted for the Ecosystem Management and Restoration Research Program. Funding to support this research was provided by the USACE Nashville District under Project Number 331898 and was supported by the following stake-holders: Tennessee Department of Environment and Conservation, The Nature Conservancy, Duck River Agency, and the Tennessee Valley Authority. The US Army Corps of Engineers (USACE) proponent for EMRRP was Mr. Greg Miller and Dr. Jennifer Seiter-Moser was the Technical Director of Environmental Engineering and Sciences which includes EMRRP. Technical review was provided by Ms. Sarah Miller and Dr. Jan Hoover.

The work was performed by the Ecological Resources (EEE) and Aquatic Ecology and Invasive Species (EEA) Branches of the Ecosystem Evaluation \& Engineering Division, US Army Engineer Research and Development Center, Environmental Laboratory (ERDC-EL). At the time of publication, Dr. Barbara L. Escalon was Acting Branch Chief of EEE; Mr. Alan Katzenmeyer was Acting Branch Chief of EEA; Mr. Mark Farr was Division Chief. The Deputy Director of ERDC-EL was Dr. Jack Davis, the Director was Dr. Edmund Russo Jr.

The authors would also like to thank Mr. Tim Wilder, Regulatory Branch Chief, LRN, for providing coordination, expertise and invaluable knowledge and insights regarding the Duck River Watershed. Mr. Carson A. Pruitt, GIS Specialist, Upper Snake Field Office, Bureau of Reclamation, Heyburn, Idaho, provided GIS data and associated maps. Mr. Robert Wallus, retired Tennessee Valley Authority, provided important insight in the methodology in the development of the Index of Biotic Integrity (IBI) used in this Special Report.

The Commander of ERDC was COL Teresa A. Schlosser and the Director was Dr. David W. Pittman.

Portions of this report were previously presented by Bruce A. Pruitt, K. Jack Killgore, W. Todd Slack, Leandro E. Miranda, and Carson A. Pruitt as "Watershed Assessment: A Multi-Scale Approach Using Ecological Modeling" at the 2017 Georgia Water Resources Conference, April 19-20, at the University of Georgia. http://gwri.gatech.edu/sites/default/files/files/docs/2017 /pruittkillgoreslackmirandapruittgwrc2017.pdf. 


\section{Introduction}

\subsection{Background}

Human activities can adversely affect ecosystems at multiple scales, from whole basins to watersheds to landscapes to stream reaches. Impacts to ecosystems include aquatic habitat alteration and loss, changes in flow regimes, land use and cover modification, and introduction of pollutants including nutrients, heavy metals, and synthetic organics-each of which can be manifested at multiple scales. The identification of pertinent biological endpoints is paramount to evaluate the cause and effect relationship between stream and watershed conditions and aquatic biota at multiple scales. Selection of a suitable statistical procedure is a requisite to establish the correspondence between physical, chemical, and biological parameters. In addition, an understanding of statistical analysis methods well suited to ecological assessment is essential to develop sampling plans, identify pertinent variables, parameters, and associated measures and formulate ecological models with application at multiple scales. Statistical analysis also maximizes the amount of information that can be used in the decision-making process and allows for extrapolation both temporally (trend analysis) and spatially (across physiographies and watersheds).

\subsection{Purpose}

The purpose of this special report is to provide a statistical, stepwise process for formulation of ecological models for application at multiple scales using a stream condition index (SCI). Given the global variability of aquatic ecosystems, this guidance is for broad application and may need to be modified to suit specific watersheds or stream reaches. However, the general statistical treatise provided herein is intended to be used across physiographies and at multiple scales. The Duck River Watershed Assessment in Tennessee was used, in part, to develop and test this multiscale, statistical approach; thus, it is considered a case example and referenced throughout this special report. The findings of this study can be used to (1) prioritize watersheds for restoration, enhancement, and conservation; (2) plan and conduct site-specific, intensive ecosystem studies, and (3) assess ecosystem outcomes (that is, ecological lift) applicable to future with and without restoration actions including alternative, feasibility, and cost-benefit analyses and adaptive management. 


\section{Model Formulation Process}

An ecological model, the SCI, was formulated according to the degree of statistical correlation (dependency) between the input parameters or variables (identified below). Several steps were undertaken pursuant to formulate and document a mathematical model (algorithm) supportive of achieving project objectives (figures $1 \mathrm{~A}$ and $1 \mathrm{~B}$ ). The following steps are described in detail below:

1. define the study area

2. compile existing data and literature references (knowledge base)

3. stratify the study area at multiple scales

4. select and test variables

5. formulate a multiscale ecological model

6. determine departure from reference conditions and rank watersheds accordingly (that is, causes and sources of impairment)

7. develop correspondence between stream condition and aquatic biota

8. validate and extrapolate the model

\subsection{Define the study area}

The study area boundaries depend on the project objectives, size, and scope, which can range from as small as a stream reach or wetland area to as large as an entire watershed. The United States Geological Survey (USGS) defines a watershed as an area of land that drains all the streams and rainfall to a common outlet such as the outflow of a reservoir, mouth of a bay, or any point along a stream channel (Perlman 2016). Watersheds can be as small as a footprint or, in the case of our example, large enough to encompass all the land that drains water into the Tennessee River from the Duck River basin, approximately 9,065 square kilometers (3,500 square miles) (figure 2).

\subsection{Develop knowledge base}

A knowledge base formally organizes entities of interest and their relation to each other in a logical framework that allows inferences about a particular problem. A knowledge base was developed by compiling biological and geomorphological data across $\mathrm{HUC} 12$ watersheds from existing fish databases. Additional stream data were collected from low-altitude, high-resolution video, resulting in a final subset of 11 of 18 stream geospatial test 
variables compiled on 213 stream segments and subjected to statistical analysis.

Several databases were compiled, reviewed, and reduced into a knowledge base pertinent to the overall Duck Watershed Assessment and ecological model development, as follows:

1. Tennessee Valley Authority (TVA) Fish Index of Biotic Integrity (IBI) data

2. National Hydrography Data set

3. TDEC Benthic Macroinvertebrate data

4. TVA and TDEC Aquatic Habitat data sets

5. Low altitude video (600 GB, 213 video segments across 64 of 87 HUC12 watersheds)

6. Numerous geospatial data sources

7. USACE National Dam Inventory

8. NRCS Web Soil Survey and SSURGO

9. Duck River Mussel Survey data set

This special report features the compelling relationship between the dynamic TVA fish data and an innovative approach to stream and watershed physical conditions using a multiscale assessment. Of the data sets identified above, TVA's IBI database provided the most robust data across the Duck River Basin. TVA made 214 fish collections between 1995 and 2014 at 88 sites in the basin (Miranda, Killgore, and Slack 2019). Consequently, the TVA's extensive IBI results offered a standardized data set to demonstrate the correspondence between the biological endpoint and the SCI. 
Figure 1. Model formulation process. Phase 1: Classification and testing; Phase 2: synthesis and application.

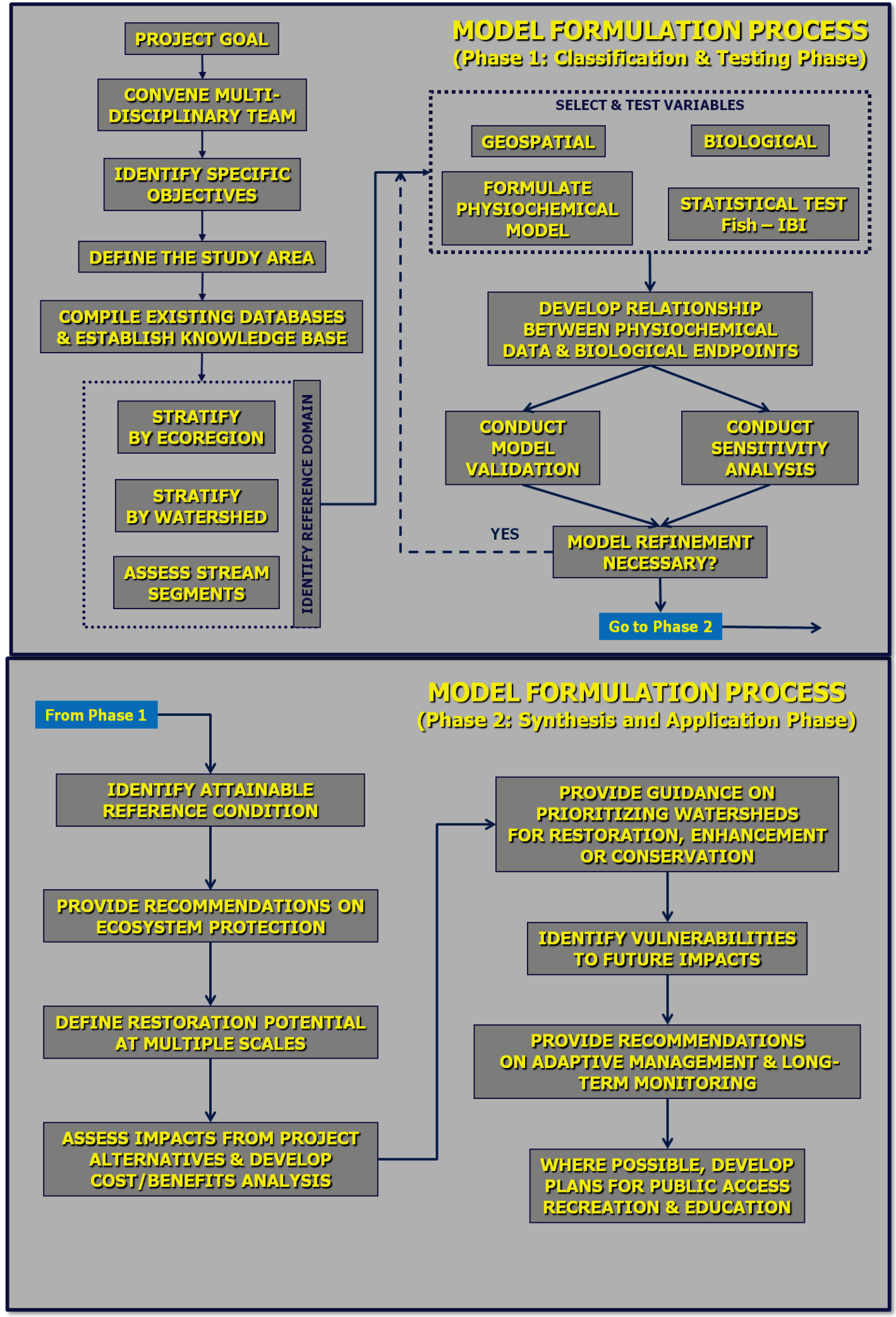


Figure 2. Tennessee Level IV Ecoregions depicting Duck River Watershed (demarcated in red) The study area included four Level 4 Ecoregions: Western Highland Rim (71f), Eastern Highland Rim (71g), Outer Nashville Basin (71h) and Inner Nashville Basin (71i).

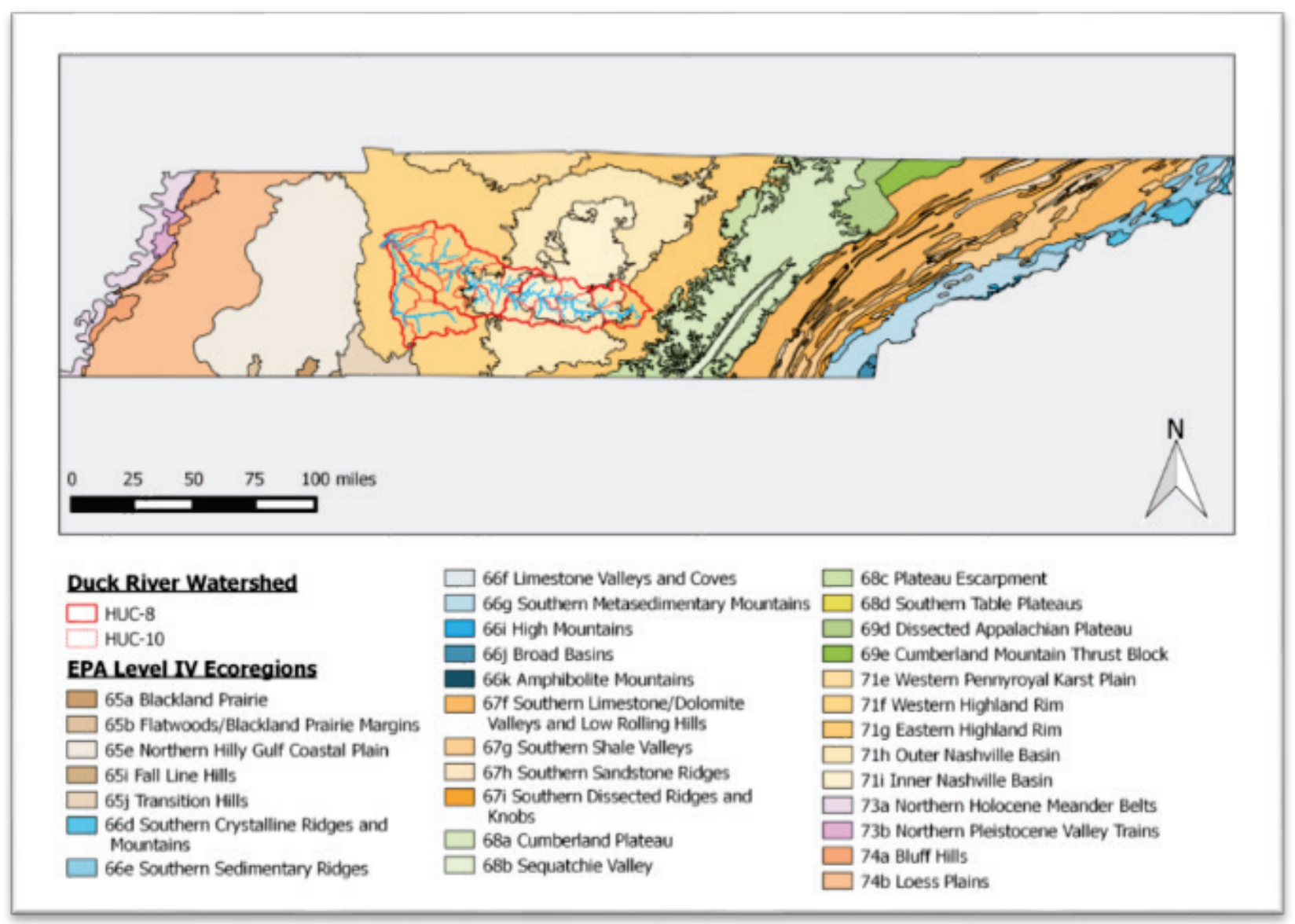

\subsection{Stratify by ecoregions and watersheds}

As with most environmental studies, there are scale considerations coupled with the need to stratify to reduce natural variability. The study area should be stratified to an ecoregion and watershed resolution (level) that is supported by the availability and spatial resolution of the data. In our example, the Duck Watershed was stratified by four Level IV Ecoregions (Griffith, Omernik, and Azevedo 1998): Western Highland Rim (71f), Eastern Highland Rim (71g), Outer Nashville Basin (71h), and Inner Nashville Basin (71i) and subdivided first into Hydrologic Unit watersheds (HUC 10) as depicted in figure 3. However, to improve resolution and extrapolation of model results, the Duck Watershed was further divided into HUC 12 watersheds as depicted in figure 8. 
Figure 3. Level IV Ecoregions and HUC10 watersheds depicting fish Index of Biotic Integrity (IBI) stations by ratings.

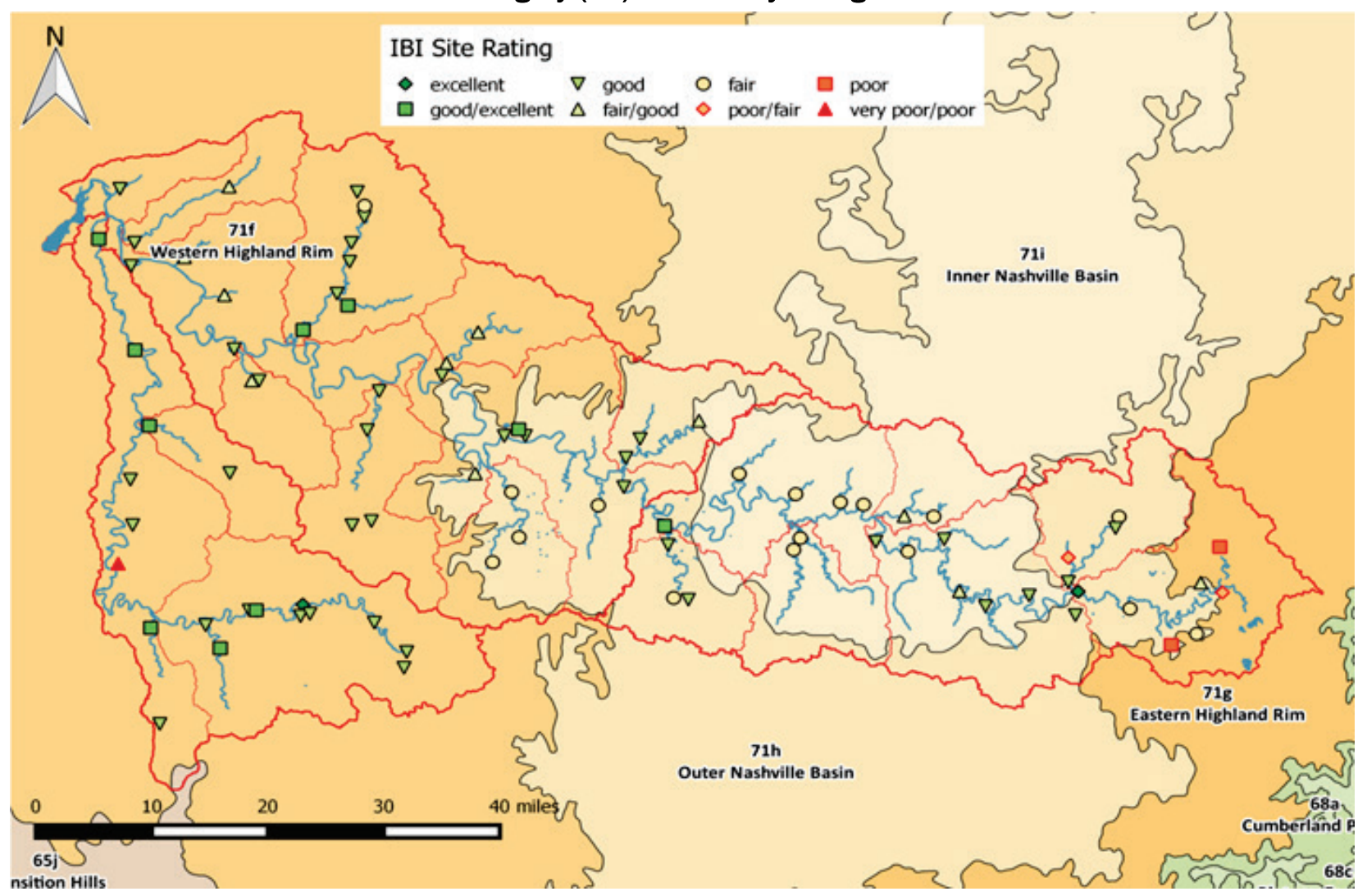

\subsection{Variable selection}

In general, variables or measures of aquatic ecosystem functions can be placed in five major categories: (1) hydrology; (2) geomorphology; (3) biogeochemistry (that is, water quality); (4) plant habitat; or (5) animal habitat. Some variables may overlap across the five categories owing to the nature of a fully integrated aquatic ecosystem. In order to reduce bias and assess a suite of aquatic ecosystem functions and associated variables, consideration should be given to each of the five major categories during reconnaissance, development of a survey or sample plan, and formulation and testing of an ecological model. In the case of the Duck Watershed Assessment, the utility of low-altitude, high-resolution video flown in February 2014 at approximately 400 feet above the stream corridor was evaluated based on 18 predetermined physical features that represented stream and riparian zone conditions (variable categories identified):

1. Stream and valley classification (all categories)

2. Channel and vegetative riparian zone width (geomorphology) 
3. Evidence of accelerated bank failure (geomorphology and biogeochemistry)

4. Evidence of head cutting (geomorphology)

5. Evidence of accelerated sediment deposition and embeddedness (geomorphology and animal habitat)

6. Evidence of active versus abandoned floodplain (hydrology and geomorphology)

7. Presence and distribution of large woody debris (animal habitat)

8. Land use and cover of the adjacent valley flat (for example, pasture grazing, crop production) (plant habitat and biogeochemistry)

9. Location and extent of rills and gullies (hydrology and geomorphology)

10. Dredging operations (hydrology and geomorphology)

11. Channelization and desnagging (hydrology, geomorphology, and plant habitat)

12. Unrestricted cattle access to stream channel (geomorphology and biogeochemistry)

13. National Pollutant Discharge Elimination System (NPDES) outfalls and discharges from MS4 areas (biogeochemistry)

14. Impoundments and low flow dams (hydrology, geomorphology, and animal habitat)

15. Discharges from dairies and confined and concentrated animal feeding operations (biogeochemistry)

16. Commercial and residential properties near the stream channel (hydrology, geomorphology, and biogeochemistry)

17. Adjacent landfills

18. Silviculture and logging road construction and maintenance (hydrology, geomorphology, biogeochemistry, and plant habitat)

The above features were tested for competency regarding identification from aerial video, ability to discriminate between stream segments and watersheds (HUC12), and capacity to determine departure from attainable reference conditions. The selection of a subset of eleven variables (listed below and defined in the appendix) was determined according to the test set and compared against the stream visual assessment protocol developed by the Natural Resource Conservation Service (NRCS) (United States Department of Agriculture 1998). Three variables used by US Department of Agriculture (USDA) - insect and invertebrate habitat, salinity, and macroinvertebrates observed-were omitted due to the remote nature of the 
aerial video and the multiscale approach. In addition, NPDES outfalls, adjacent landfills, and silviculture were omitted due to inability to discern these features remotely.

\subsection{Formulate Stream Condition Index (SCI)}

The Duck River Watershed Assessment was used, in part, to develop and test a statistical approach to assess ecosystems using multiple attributes across multiple scales, called the "Multiscale Watershed Approach" (MSWA). A total of 213 low-altitude, high-resolution video segments were flown by Red Hen Systems, Colorado, at an altitude of approximately 400 feet above ground surface across 64 of 87 HUC12 watersheds. The SCI was formulated using eleven variables representing instream aquatic habitat, riparian, and watershed-valley conditions. SCI scores were calculated from average variable scores of video segments within each of the 64 watersheds where low-altitude, high-definition video was provided. SCI scores were estimated in the remaining 23 watersheds by quantile regression. Significant correlations were determined according to regression analysis ( $F$-test, $p<0.01$ ) (table 1). The values of each of the variables were subjected to Spearman's $r$ correlation and tabulated in a product matrix (table 2). Direct and indirect correlations were summarized (table 3). The effect of embeddedness, which was observed to correspond to 9 of the other 10 model variables, was noteworthy by emphasizing the power of using statistical analysis in model formulation. No significant correlations were observed between dams and other variables; thus, it was not used in the model. Consequently, the following variables represent 11 of the 15 variables recommended by NRCS:

$$
S C I=\left(\frac{\sqrt[3]{C S \times F C \times P}+\sqrt[3]{R Z \times B S \times C A N}}{2}+\frac{H A+\sqrt[3]{W C \times N E \times E M B}+C A}{3}\right) / 2
$$

where

$$
\begin{array}{ll}
C S=\text { channel stability } & H A=\text { hydrologic alteration } \\
F C=\text { fish cover } & W C=\text { water color } \\
P=\text { pools } & N E=\text { nutrient enrichment } \\
R Z=\text { riparian zone } & E M B=\text { embeddedness } \\
B S=\text { bank stability } & C A=\text { cattle access } \\
C A N=\text { canopy density } &
\end{array}
$$


As used herein, ecological models are algorithms that combine variables according to their statistical correlation. For example, channel stability, fish cover, and pools were observed to be correlated and interact with each other (table 1). Interaction is analogous to dependence, where a variable has a statistically significant influence on other variables. This observed interaction between the three variables exert a simultaneous influence on a model score and thus is not additive. Consequently, they were combined and normalized to 1.0 by taking the geometric mean. The same standard was applied to the two other combined variables under the radical in the SCI. In contrast, hydrologic alteration and cattle access were not statistically correlated with other variables. Consequently, they are considered independent and are incorporated in the SCI by taking the arithmetic mean. 
Table 1. Linear regression analysis, $T$-test, $p$-values, correspond with correlations presented in table 7 (highlighted values are significant at $p<0.01$ and coincide with the correlations in table 2).

\begin{tabular}{|l|l|l|l|l|l|l|l|l|l|l|l|l|l|}
\hline CS & HA & RZ & BS & WC & NE & DAMS & FC & P & CAN & CA & EMB & Symbol & Variable \\
\hline 1.00 & -0.74 & 0.84 & 0.76 & -0.46 & -0.42 & 0.28 & 0.64 & 0.75 & 0.59 & -0.03 & -0.66 & CS & Channel Stability \\
\hline & 1.00 & -0.78 & -0.50 & 0.17 & 0.25 & -0.24 & -0.55 & -0.59 & -0.55 & 0.30 & 0.48 & HA & Hydrologic Alteration \\
\hline & & 1.00 & 0.73 & -0.34 & -0.37 & 0.27 & 0.47 & 0.65 & 0.60 & -0.13 & -0.54 & RZ & Riparian Zone \\
\hline & & & 1.00 & -0.61 & -0.56 & 0.11 & 0.50 & 0.63 & 0.43 & -0.03 & -0.61 & BS & Bank Stability \\
\hline & & & & 1.00 & 0.56 & 0.19 & -0.38 & -0.41 & -0.25 & -0.15 & 0.64 & WC & Water Color \\
\hline & & & & & 1.00 & 0.08 & -0.49 & -0.51 & -0.29 & 0.17 & 0.54 & NE & Nutrient Enrichment \\
\hline & & & & & & 1.00 & 0.08 & 0.21 & 0.17 & 0.09 & -0.09 & DAMS & Structural Dams \\
\hline & & & & & & 1.00 & 0.83 & 0.30 & -0.27 & -0.48 & FC & Fish Cover \\
\hline & & & & & & & 1.00 & 0.44 & -0.10 & -0.51 & P & Pools \\
\hline & & & & & & & & 1.00 & -0.05 & -0.56 & CAN & Canopy Closure \\
\hline & & & & & & & & & 1.00 & -0.01 & CA & Cattle Access \\
\hline
\end{tabular}


Table 2. Correlation product matrix on stream variables, significant correlations for positive and negative relationships highlighted green and magenta, respectively.

\begin{tabular}{|c|c|c|c|c|c|c|c|c|c|c|c|c|c|}
\hline CS & $\mathrm{HA}$ & $\mathrm{RZ}$ & BS & WC & $\mathrm{NE}$ & DAMS & FC & $P$ & CAN & $\mathrm{CA}$ & EMB & Symbol & Variable \\
\hline \multirow[t]{12}{*}{1.0000} & 0.0000 & 0.0000 & 0.0000 & 0.0001 & 0.0007 & 0.0232 & 0.0000 & 0.0000 & 0.0000 & 0.8298 & 0.0000 & CS & Channel Stability \\
\hline & 1.0000 & 0.0000 & 0.0000 & 0.1944 & 0.0515 & 0.0568 & 0.0000 & 0.0000 & 0.0000 & 0.0000 & 0.0001 & $\mathrm{HA}$ & Hydrologic Alteration \\
\hline & & 1.0000 & 0.0000 & 0.0059 & 0.0031 & 0.0287 & 0.0001 & 0.0000 & 0.0000 & 0.3082 & 0.0000 & RZ & Riparian Zone \\
\hline & & & 1.0000 & 0.0000 & 0.0000 & 0.3906 & 0.3076 & 0.0000 & 0.0004 & 0.8158 & 0.0000 & BS & Bank Stability \\
\hline & & & & 1.0000 & 0.0000 & 0.1462 & 0.0021 & 0.0009 & 0.0514 & 0.2418 & 0.0000 & WC & Water Color \\
\hline & & & & & 1.0000 & 0.5326 & 0.0000 & 0.0000 & 0.0216 & 0.1826 & 0.0000 & $\mathrm{NE}$ & Nutrient Enrichment \\
\hline & & & & & & 1.0000 & 0.5094 & 0.0987 & 0.1879 & 0.4730 & 0.5063 & DAMS & Structural Dams \\
\hline & & & & & & & 1.0000 & 0.0000 & 0.0160 & 0.0316 & 0.0001 & $\mathrm{FC}$ & Fish Cover \\
\hline & & & & & & & & 1.0000 & 0.0003 & 0.4516 & 0.0000 & $\mathbf{P}$ & Pools \\
\hline & & & & & & & & & 1.0000 & 0.6804 & 0.0000 & CAN & Canopy Closure \\
\hline & & & & & & & & & & 1.0000 & 0.9123 & CA & Cattle Access \\
\hline & & & & & & & & & & & 1.0000 & EMB & Embeddedness \\
\hline
\end{tabular}


Table 3. Direct and indirect correlations between model variables (variables as above; embeddedness [EMB], emphasized).

\begin{tabular}{|l|}
\hline Channel Stability $\sim$ RZ, BS, FC, Can, 1/HA, 1/WC, 1/NE, 1/EMB \\
\hline Hydrologic Alteration EMB, 1/RZ, 1/BS, 1/FC, 1/P, 1/CAN \\
\hline Riparian Zone BS, FC, P, CAN, CS, 1/HA, 1/EMB \\
\hline Bank Stability CS, RZ, FC, P, CAN, 1/EMB \\
\hline Water Color NE, EMB, 1/P, 1/CS, 1/BS \\
\hline Nutrient Enrichment EMB, WC, 1/FC, 1/P, 1/CS, 1/BS \\
\hline Structural Dams none \\
\hline Fish Cover $\sim$ P, RZ, BS, 1/EMB, 1/HA, 1/NE \\
\hline Pools CAN, CS, RZ, BS, 1/NE, 1/EMB \\
\hline Canopy Closure CS, RZ, BS, P, 1/HA, 1/EMB \\
\hline Cattle Access none \\
\hline Embeddedness HA, WC, NE, 1/CS, 1/RZ, 1/BS, 1/FC, 1/P, 1/CAN \\
\hline
\end{tabular}

\subsection{Identify attainable reference conditions}

Attainable reference conditions can be reasonably established by identifying best attainable conditions (BAC) within a given ecoregion, watershed, or stream segment (Stoddard et al. 2006). The limits of BAC are set by the definitions of minimally disturbed condition (upper limit) and least disturbed condition (lower limit) (Pruitt et al. 2012). Establishment of attainable reference conditions (Stoddard et al. 2006) according to aquatic diversity and habitat is fundamental to develop a gradient of impacts from which departure from reference conditions can be assessed (figure 4). Types of reference conditions can be on-site or off-site analogs, historical, constructed, or by creating a regional index. Reference sites provide a scale to compare the condition of other sites against. In addition to establishing achievable performance standards, monitoring analog reference sites in conjunction with restoration sites is paramount to address variation with respect to normal seasonal fluctuations, drought, climate change, and catastrophic events (force majeure), which may not accurately reflect the cause of success or failure due to restoration actions. 
Figure 4. Stream condition index (SCl) scaled against environmental disturbance gradient (adapted from Pruitt et al. 2012). Twenty-three percent of the Duck watershed is considered "minimally disturbed to relatively undisturbed", $44 \%$ is "minor disturbance to biotic and abiotic attributes", and $32 \%$ is "major or severe disturbance to biotic and abiotic attributes."

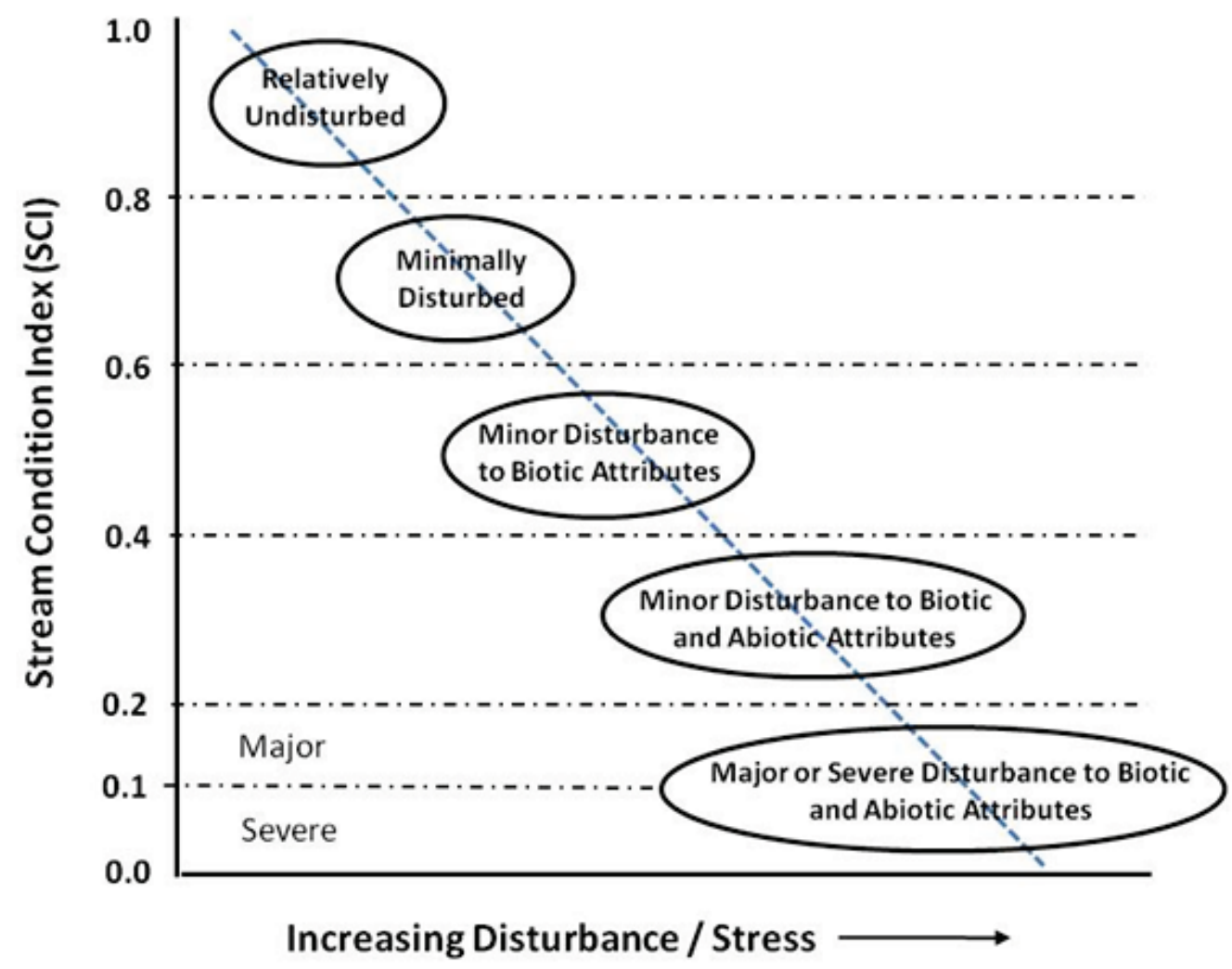

In order to determine departure from reference conditions in the Duck Watershed, reference watersheds and associated stream segments were identified within each HUC12 watershed, if present. If the natural variation associated with the attributes across reference watersheds was insignificant, the reference watersheds were aggregated for comparison against other watersheds considered impaired. Watersheds with similar types and degree of impairment were aggregated as well. Primer computer software that includes ordination methods facilitated this process (Clarke and Gorley 2015).

Stressors are factors caused by human activities (for example, loss of aquatic habitat, pollutants) or by natural events (for example, extreme storms, extended drought) that result in aquatic ecosystem impairment or degradation. Ecosystem impairment was identified at ecoregion and wa- 
tershed scales by analyzing fish index of biotic integrity (IBI) data provided by the Tennessee Valley Authority (TVA), which included 88 biological stream stations. The TVA has been collecting fish data in the Tennessee River system since 1986 and developed the IBI to monitor trends of the fish community. TVA established fixed and random monitoring stations to evaluate the watershed and levels of human disturbance such as pointsource discharge and non-point source runoff. TVA developed the IBI as an environmental assessment tool following the procedure of Karr (1981). Twelve metrics addressed species richness and composition, trophic structure, fish abundance, and fish condition. Scores for the 12 metrics are summed to produce the IBI value for the site. The IBI database was provided by TVA (Evan Crews and Terry O'Quinn) along with descriptions of the protocols used in data collection.

Initially, several fish and one macroinvertebrate index, EPT, were subjected to nonmetric multidimensional scaling across the four Level 4 Ecoregions (figure 5) (Griffith, Omernik, and Azevedo 1998).The EPT Index is the total number of distinct taxa within the insect orders Ephemeroptera, Plecoptera, and Trichoptera, and which are generally accepted to be indicators of good water quality (that is, pollution intolerant). Excellent grouping and statistical gradients (similarity and dissimilarity) were observed on IBI scores in reference to Outer and Inner Nashville Basin and Western Highland Rim Ecoregions, and a fair relationship was observed on the Eastern Highland Rim data set due to low sample density. Metric scores were higher in the Western Highland Rim Ecoregion, indicating less anthropogenic disturbances. The results of this initial ordination were used to identify those ecoregions with potentially higher impairment according to biotic metrics and then explore the relationship between physical geospatial data and biological data and, ultimately, model (algorithm) formulation. 
Figure 5. Nonmetric multidimensional scaling on fish IBI data across Level IV Ecoregions, Duck River watershed, Tennessee. Biotic metrics were higher in the Western Highland Rim ecoregion, moderate in the Inner Nashville Basin, variable in the Outer Nashville Basin, and consistently lower in the Eastern Highland Rim. Changes in the biotic metrics can be compared to descriptions of anthropogenic development in the Ecoregions as an approach to evaluate baseline conditions.

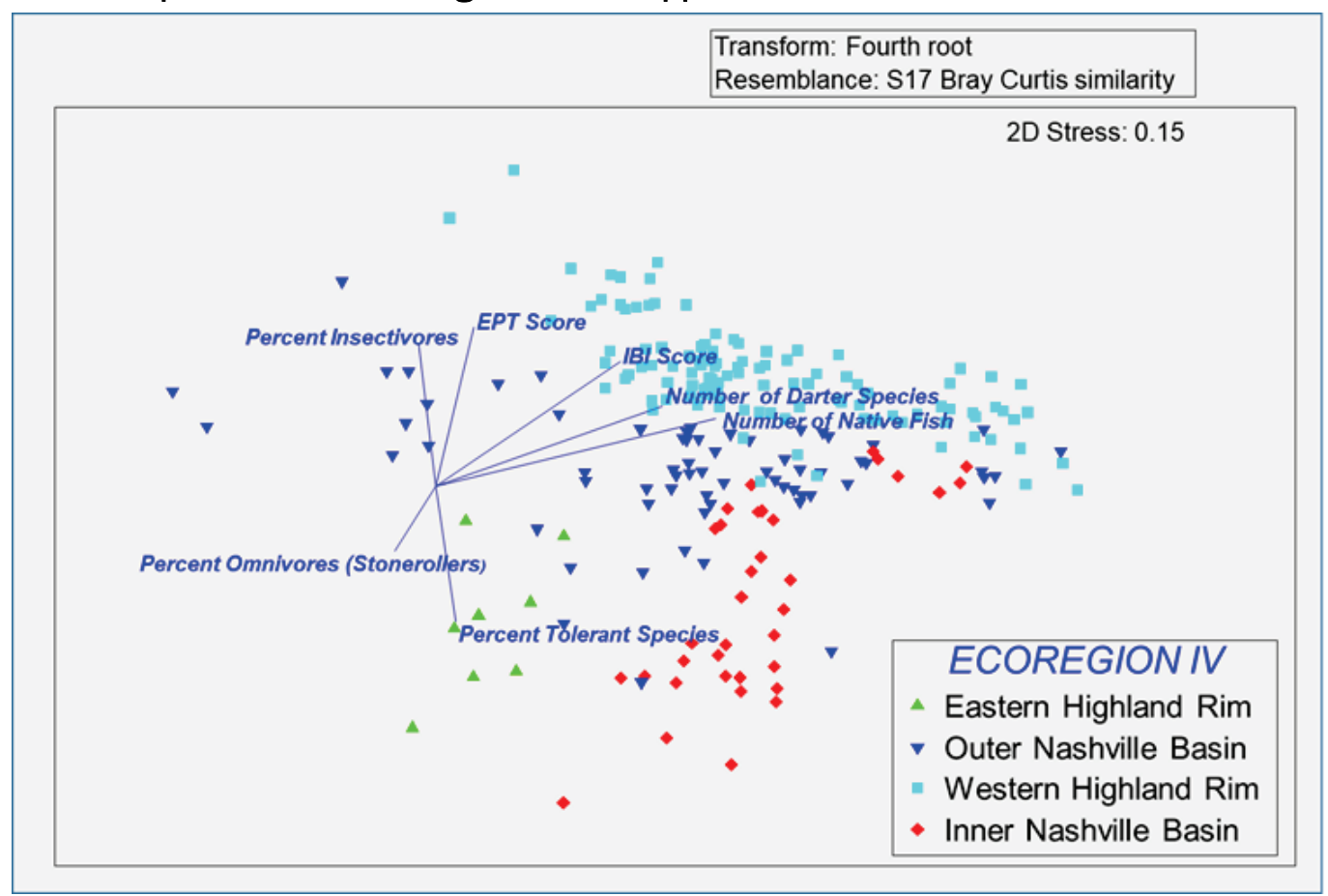

\subsection{Stream condition and aquatic biota correspondence}

The relationship between the SCI and a biological response was conducted using the Tennessee Valley Authority's Index of Biotic Integrity (IBI) database. Ordination of fish species abundance among sites showed a pattern of IBI ratings with lower scores clearly separated from excellent scores (figure 6). Vector fitting indicated that sites with higher IBI ratings were associated with greater canopy and channel stability, while sites with lower IBI ratings occurred at sites with higher water color, nutrient enrichment, embeddedness, and hydrologic alteration.

\subsection{Model validation}

Validation is a demonstration that a model within its domain of applicability possesses a satisfactory range of accuracy consistent with the intended application of the model (Rykiel 1996). The validity of the SCI was tested by advancing the relationship between the SCI and a biological response, which was assessed using the TVA's IBI database. We compared the SCI to IBI scores. A bivariate plot of SCI (normalized to $0-1$ ) and IBI scores 
showed a statistically significant, wedge-shaped distribution (figure 7), suggesting that anthropogenic change in habitat quality acts as a limiting factor. This analysis also indicates a positive relationship between increasing SCI and IBI scores. Wedge-shape bivariate relationships violate the assumptions of ordinary least squares regression and are better described by quantiles of the dependent variable (Dunham et al. 2002). An advantage of using quantile regression to model heterogeneous variation in response distributions is that the data do not have to be normally distributed; nor is there any restriction to the exponential family of distributions (Cade and Noon 2003). Consequently, an algorithm was formulated that predicts SCI as a function of IBI score for 55 sites where the two variables co-occurred (figure 7). This relationship indicates that either IBI score can predict SCI or vice versa, which provides a tool to predict both stream conditions and status of the fish assemblage.

Figure 6. Nonmetric multidimensional scaling ordinations of fish species among sites. Symbols represent IBI rating of each site. Vectors identify the direction and strength of correlations. The boxes summarize quadrat characteristics. Analysis indicates that IBI and $\mathrm{SCl}$ scores decrease due to anthropogenic disturbances and can identify restoration projects that increase biotic diversity.

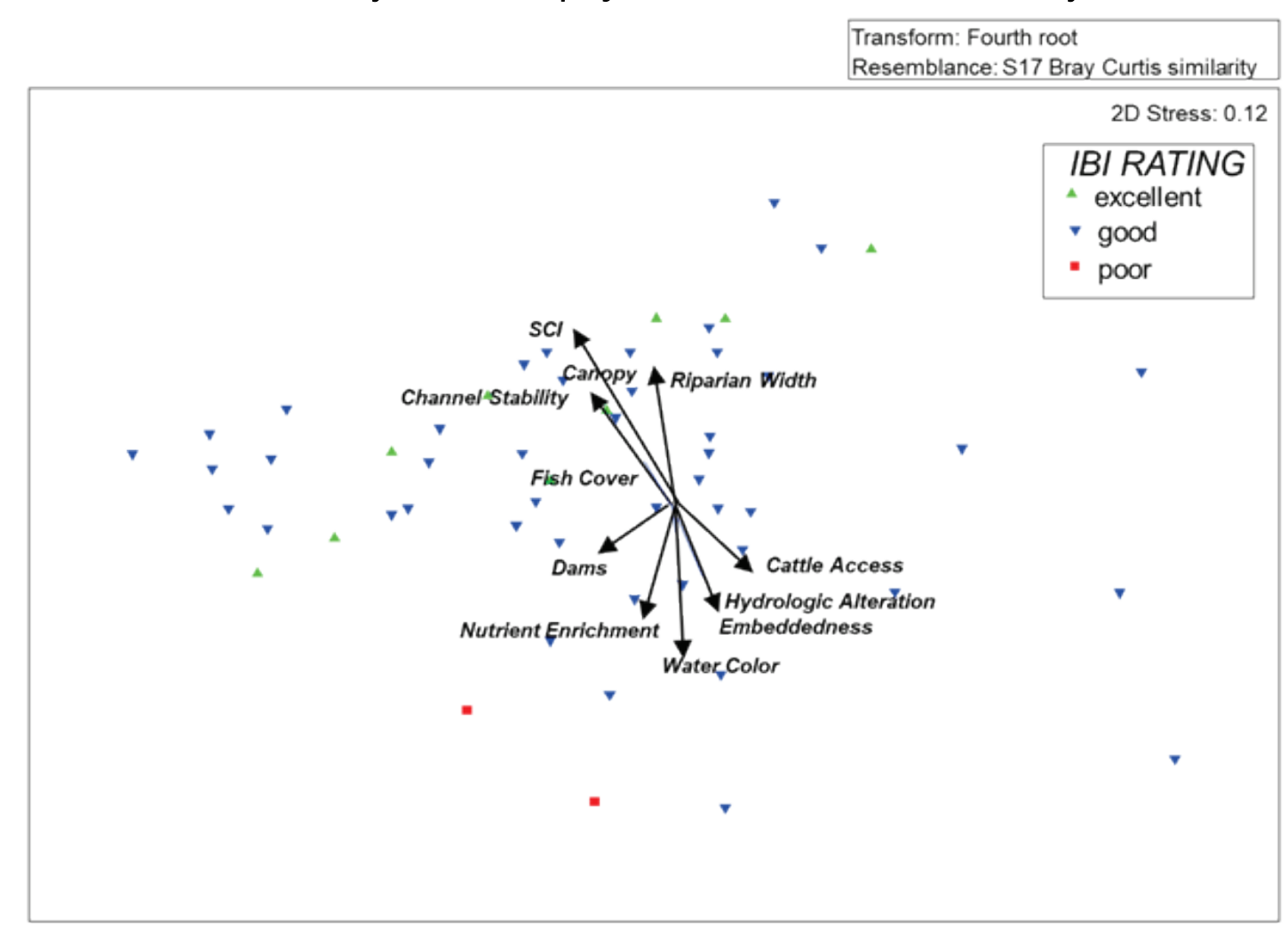


Figure 7. Estimate of the 90th quantile regression equation with $95 \%$ confidence limits for Stream Condition Index (normalized to $0-1$ ) as a function of the IBI.

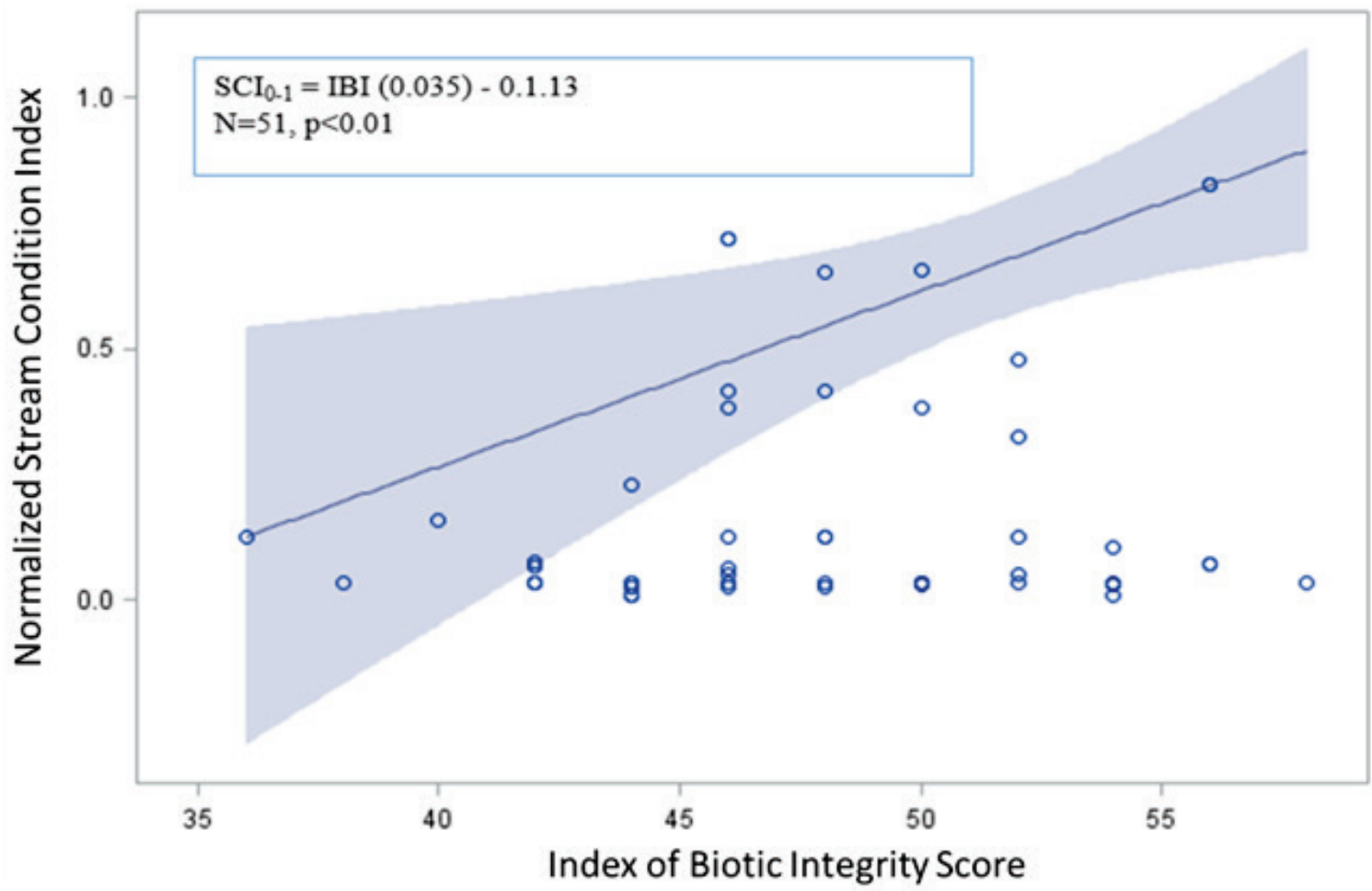

\subsection{Application of Stream Condition Index}

Two hundred thirteen video segments across 64 of $87 \mathrm{HUC} 12$ watersheds were evaluated using the 11 variables listed above. SCI scores were calculated from average variable scores of video segments within each of the 64 watersheds and mapped in figure 8 . Twenty of the 87 watersheds were considered to exhibit "major or severe disturbance to biotic and abiotic attributes" (SCI <0.2) (figure 4). Thirty-nine of the 87 watersheds were considered to exhibit "minor disturbance to biotic and abiotic attributes" that included scores extrapolated by regression analysis described below (SCI 0.2-0.6), and 28 of the 87 watersheds exhibited "minimally disturbed to relatively undisturbed" that included scores extrapolated by regression analysis ( $\mathrm{SCI}>0.6)$.

The ability to extrapolate across different scales is a powerful tool and can be determined using statistical analysis. In the Duck watershed study, 23 of $87 \mathrm{HUC12}$ watersheds were not assessed directly using the SCI since video photogrammetry was not available for those watersheds. Consequently, the SCI was regressed against total developed land (figure 9). An 
algorithm was formulated capable of estimating the SCI from land use derived from satellite imagery (GIS) from watersheds that were not assessed directly by low-altitude video or surface assessments. The SCI for 4 of the 23 watersheds calculated by regression analysis were "minimally disturbed to relatively undisturbed" (SCI >0.6). The SCI for 19 of the 23 watersheds were considered "minor disturbance to biotic and abiotic attributes" (SCI 0.2-0.6).

At the entire Duck basin scale, $23 \%$ of the Duck watershed is considered "minimally disturbed to relatively undisturbed", $44 \%$ is "minor disturbance to biotic and abiotic attributes", and $32 \%$ is "major or severe disturbance to biotic and abiotic attributes".

Figure 8. SCl scores per HUC12 watersheds, Duck River watershed, Tennessee. By comparing figures 4 and 8,20 of the 87 watersheds experienced "major or severe disturbance to biotic and abiotic attributes" $(\mathrm{SCl}<0.2)$. Thirty-nine of the 87 watersheds experienced "minor disturbance to biotic and abiotic attributes" ( $\mathrm{SCl}$ $0.2-0.6$ ), and 28 of the 87 watersheds experienced "minimally disturbed to relatively undisturbed" $(\mathrm{SCl}>0.6)$.

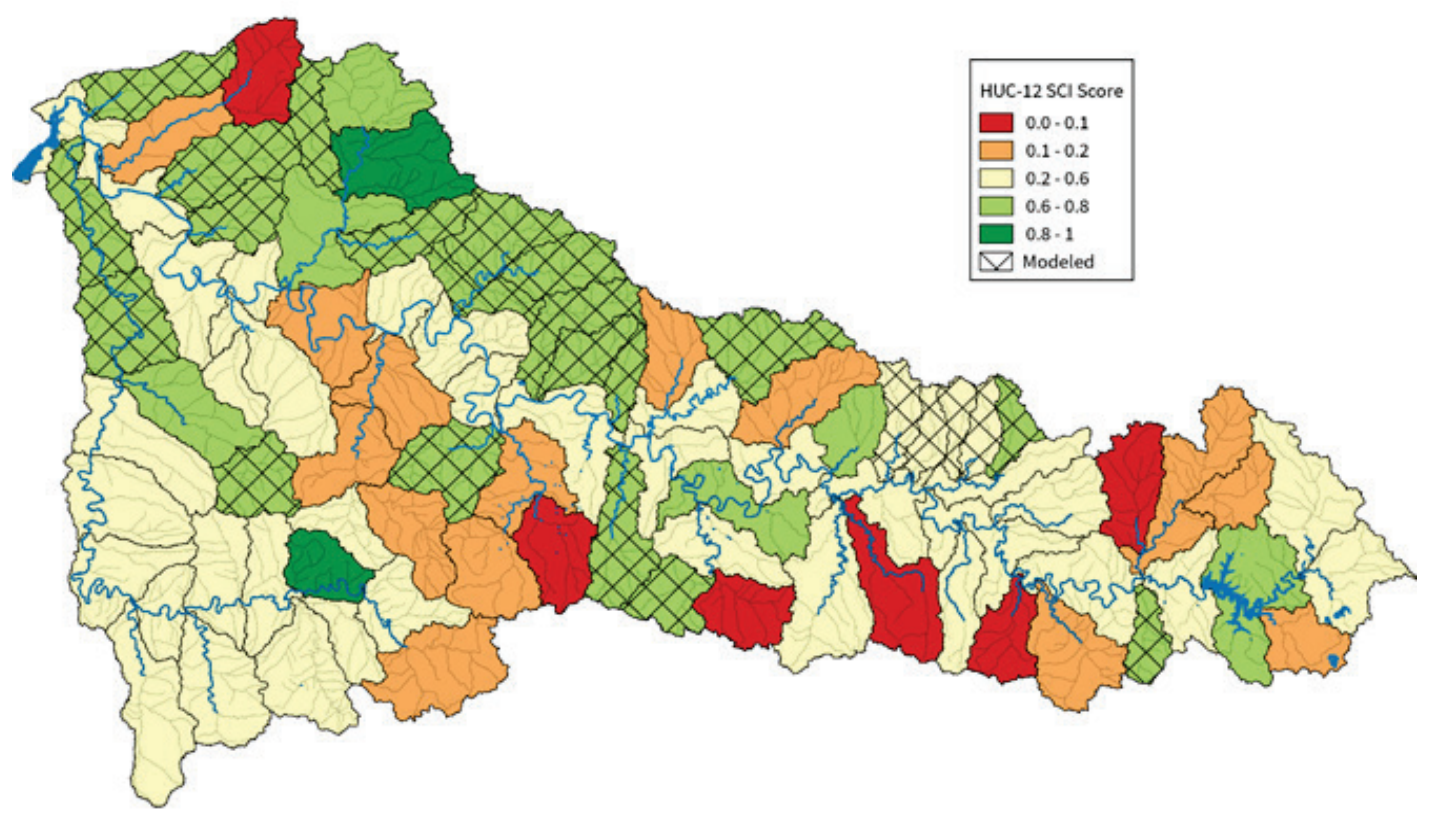


Figure 9. Estimate of the 90th quantile regression equation for $\mathrm{SCl}$ (normalized to 0 1) as a function of total developed land. The equation was used to predict $\mathrm{SCl}$ scores for HUCs without monitoring data but with estimates of total developed land.

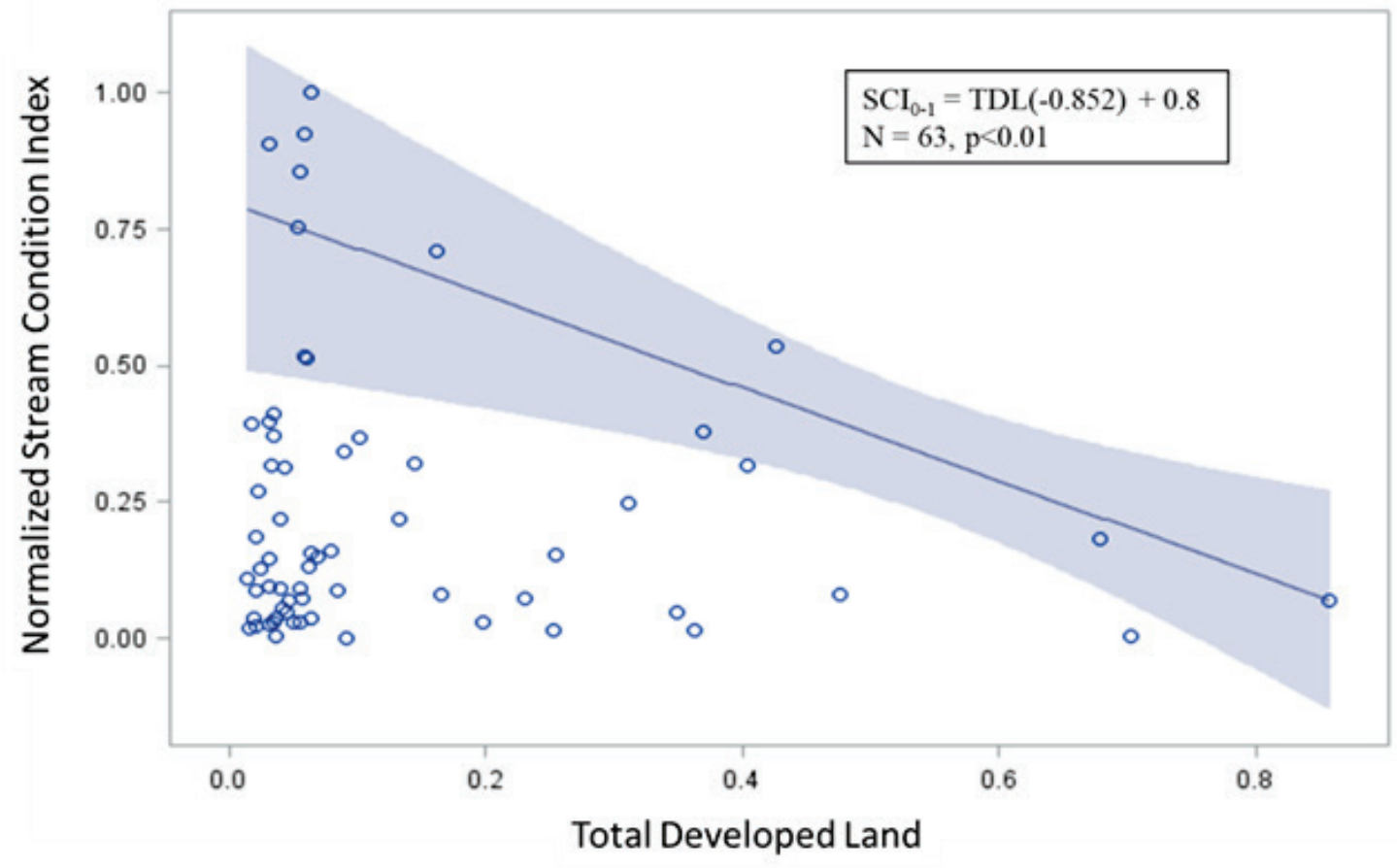




\section{Conclusions and Discussion}

General guidance for the planning process and conducting watershed assessments are provided in the Planning Bulletins (PB), Engineer Circulars (EC) and Regulations (ER). In particular, the PB 2016-03 outlining the watershed studies (most current guidance) and the following sections regarding the watershed plans in EC-1105-2-411 (section 8, Watershed Planning Process) and the planning guidance notebook, ER1105-2-100 (2-2 and E-2), are helpful. In general, the guidance for watershed studies provides a six-step watershed planning process:

1. Identify problems and opportunities.

2. Inventory and forecast conditions.

3. Identify and screen measures.

4. Formulate initial array of strategies.

5. Refine initial array and evaluate focused array of strategies.

6. Strategy comparison and selection.

The procedure outlined in this report can be used directly for several of the above steps, including identify problems and opportunities; inventory (baseline) and forecast conditions; formulating, evaluating, and comparing alternative approaches; and strategic selections to prioritize watersheds for restoration, enhancement, and conservation. The SCI presented herein can also be used to plan and conduct site-specific, intensive ecosystem studies and assess ecosystem outcomes (that is, ecological lift) applicable to future with and without restoration actions including alternative, feasibility, and cost-benefit analyses and adaptive management.

The Duck River Watershed Assessment was used, in part, to develop and test this multiscale, statistical approach; thus, it is pertinent to the purpose of this report. Located in the Interior Plateau, Tennessee, the Duck Watershed Assessment represents a new method of assessing ecosystems using multiple attributes across multiple scales, called the Multiscale Watershed Approach (MSWA). The concept behind the MSWA sought to establish a means of using readily available data to create an overall knowledge base collected by multiple agencies and stakeholders. The outcome of the MSWA can become the principle component of the decision-making process such that water resource managers have the ability to make scientifically defensible decisions not only at project-specific scales but also 
beyond the footprint of the project to the entire watershed. From the watershed perspective, the cause and effect relationships between land use, water quality and quantity, in-channel and riparian conditions, and biotic responses culminate at a single outlet that represents the cumulative ecological condition of the watershed. In addition, assessment at the watershed scale offers advance planning, including design; construction; and operation, maintenance, repair, replacement and restoration of aquatic ecosystems. By formulating an SCI, additional stream segments or watersheds can be evaluated in the future. The results of the future assessments can be compared against the Duck Watershed Assessment and Plan.

In addition to the analysis of geospatial data using the SCI, fish IBI scores were evaluated in the Duck Watershed Assessment according to 12 metrics, which addressed species richness and composition, trophic structure, fish abundance, and fish condition. Scores for the 12 metrics were summed to produce the IBI value for the site. By comparing the SCI to IBI scores, aquatic biota impairment was found to occur predominantly due to loss of streamside canopy, reduction of in-stream cover, and impacts to channel stability, all of which were considered to be limiting factors in regards to sustaining a healthy aquatic ecosystem in the Duck River watershed.

Ecological models such as the SCI help define the problem and identify opportunities, make clear the relationship between the physicochemical and biological functions of an aquatic ecosystem, provide analytical tools to enhance data annotation and synthesis, enable comparisons between and across ecosystem types and physiography, and accommodate communication regarding ecological processes and functions across scientific disciplines and to the public. In addition, a process-based approach was applied to the Duck Watershed assessment that identified critical processes and pathways regarding the cause and effect relationship between geospatial data (for example, embeddedness) and aquatic biota (fish IBI). The Duck Watershed Assessment and ecological modeling is unique, original work for the following reasons:

1. Over the past four decades, watershed assessments have evolved through three predominant scales, surface (boots on the ground) to manned aircraft photography (various altitudes) to satellite imagery (over 400 miles altitude). However, with the advent of readily available satellite imagery and computer software, high-definition video and photography collected from aircraft has been underutilized. This study 
demonstrated a rapid, precise and relatively inexpensive means of collecting physical and biological data at much higher resolution than satellite imagery.

2. The SCI model was formulated using statistical methods, consequently reducing bias and subjectivity (tables 2 and 3 ).

3. The SCI model was formulated and tested independently of the fish IBI interpretation and statistical analysis. Consequently, the results of the IBI data confirmed the SCI model.

4. The use of a biological endpoint (fish IBI) reduced uncertainty in the use of the SCI model and ensures its successful use in aquatic life protection.

5. The algorithm that predicts SCI as a function of IBI score (figure 9) is noteworthy in that either IBI score can predict SCI or vice versa. Consequently, by conducting a visual assessment of stream condition using the SCI, conclusions can be made regarding fish diversity and distribution within a stream segment or a defined watershed.

On the basis of the SCI scores calculated across 64 HUC12 watersheds, the following can be concluded for the Duck River watershed:

1. Sediment in the form of embeddedness was the predominant cause of aquatic habitat loss. Embeddedness affected 9 of the other 10 variables (table 3).

2. Embeddedness was indirectly correlated to channel and bank stability, riparian zone condition, and canopy closure and directly related to hydrologic alteration, water color, and nutrient enrichment (table 2).

3. Agricultural practices and cattle access contributed to bank failure and erosion, leading to high sediment loadings as evidenced by the condition of the riparian zone and bank stability.

4. As evidenced by reduction in fish cover and pools, fish and aquatic benthic habitat were adversely affected by embeddedness, hydrologic alteration, and nutrient enrichment.

Overall, the results of SCI-IBI scores observed in the Duck Watershed assessment can be used in the planning process to

1. Prioritize stream segments and watersheds for restoration, enhancement, preservation (conservation), and future risk of aquatic impacts.

2. Assess proposed project alternative analysis and cost-benefit analysis. 
3. Develop performance standards and success criteria applicable to restoration actions.

4. Address impacts or improvements beyond the footprint of the project.

5. Establish monitoring plans including adaptive management.

6. Forecast future ecosystem outcomes.

7. Estimate the long-term effects of climate change on ecosystem processes and functions.

8. Assess stream conditions elsewhere and compare against reference conditions established during this watershed assessment.

9. Justify proposed projects at the national significant priority scale.

The importance of incorporating biological endpoints in aquatic ecosystem assessments and restoration efforts cannot be over emphasized. That importance is written into USACE guidance, "ecosystem restoration objectives are clearly written statements that prescribe specific actions to be taken to improve the ecosystem, or fish and wildlife resources" (ER1105_2-100 2000, 2-2 and E-2). Ecosystem models that only account for physical habitat may not actually restore, protect or sustain aquatic biota (that is, field of dreams misconception). In this study, biosystems modeling, which incorporates biological endpoints, reduced the uncertainty in successful ecosystem restoration actions that do not fully meet project objectives supportive of a suite of aquatic functions and benefits.

The statistical treatise used in model development for the Duck Watershed Assessment can be used elsewhere in other physiographies and USACE districts. The protocol used herein for establishing stream corridor conditions is applicable to the Tennessee River basin within Tennessee. However, the protocol can be transported to other river basins with additional beta testing and model refinement. 


\section{References}

Baglin, J. 2014. "Improving Your Exploratory Factor Analysis for Ordinal Data: A Demonstration Using FACTOR Practical Assessment." Research and Evaluation 19 (5). Available online: http://pareonline.net/getvn.asp?v=19\&n=5.

Balon, E. K. 1975. “Reproductive Guilds of Fishes: A Proposal and Definition.” Journal of the Fisheries Research Board of Canada. 32:821-864.

Cade, B. S. and B. R. Noon. 2003. "A Gentle Introduction to Quantile Regression for Ecologists." Front Ecol Environ 1(8): 412-420.

Clarke, K.R. and R.N. Gorley. 2015. PRIMER v7: User Manual/Tutorial. Devon, United Kingdom: PRIMER-E. http://updates.primer-e.com/primer7/manuals /User_manual_v7a.pdf

Cochran, W.G., F. Mosteller, and J.W. Tukey. 1954. "Principles of Sampling.” Journal of the American Statistical Association 49: 13-35.

CPWS (Columbia Power \& Water Systems). 2011. Drought Management Plan. December 2011.

Cushman, R.M. 1985. "Review of the Ecological Effects of Rapidly Varying Flows Downstream from Hydroelectric Facilities.” North American Journal of Fisheries Management 5:3A, 300-339.

Dunham, Jason B., Brian S. Cade and James W. Terrell.2002. "Influences of Spatial and Temporal Variation on Fish-Habitat Relationships Defined by Regression Quantiles," Transactions of the American Fisheries Society 131(1): 86-98.

Etnier, D. A., and W. C. Starnes. 1993. The Fishes of Tennessee. Knoxville, TN: University of Tennessee Press.

Griffith, G.E., J.M. Omernik, and S.H. Azevedo. 1998. Ecoregions of Tennessee. (2 sided color poster with map, descriptive text, summary tables, and photographs). Reston, VA: US Geological Survey. Scale 1:940,000.

Hobbs, D. 2015. Lower Duck River: Mussel Survey and Inventory. Tennessee Wildlife Resources Agency.

Hobbs, D. 2016. 2015 Duck River Quantitative Mussel Survey. Fisheries Report 16-o6. Aquatic Habitat Protection Program and Tennessee Wildlife Management Agency.

Hutson, S.S. 2008. Estimated use of water in the upper Duck River watershed, central Tennessee, and water-demand projections through 2030: US Geological Survey Scientific Investigations Report 2008-5058, 16 p.

Karr, J. R. 1981. “Assessment of Biotic Integrity Using Fish Communities.” Fisheries (Bethesda). 6(6):21-27. 
Kerans, B. L., J. R. Karr.1994. “A Benthic Index of Biotic Integrity (B-IBI) for Rivers of the Tennessee Valley.” Ecological Applications 4(4):768-785.

Knight, R.R. and J.A. Kingsbury. 2007. Water Resources of the Duck River Watershed, Tennessee. US Geological Survey Scientific Investigation Report 2007-5105, 46 pp.

Knight, R.R., J.C. Murphy, W.J. Wolfe, C.F. Saylor and A.K. Wales. 2013. "Ecological Limit Functions Related to Fish Community Response to Hydrologic Departures of the Ecological Flow Regime in the Tennessee River Basin, United States.” Ecohydrology. Wiley Online Library.

Lee, D. S., C. R. Gilbert, C. H. Hocutt, R. E. Jenkins, D. E. McAllister, and J. R. Stauffer, Jr.1980. Atlas of North American Freshwater Fishes. Publication No. 1980-12. Raleigh, NC: North Carolina State Museum of Natural History.

Lin, J.P., R.D. Smith, and B.A. Kleiss. 2008. Using a Multi-scale Assessment of Watershed Integrity (MAWI) Approach for Establishing Baseline Conditions in Watersheds. ERDC/EL TR-o8-14. Vicksburg. MS: Engineer Research and Development Center.

Lyons, J., L. Wang, T. D. Simonson. 1996. "Development and Validation of an Index of Biotic Integrity for Coldwater Streams in Wisconsin." North American Journal of Fisheries Management 16: 241-256.

Miranda, L. E., K.J. Killgore and W.T. Slack. 2019. "Spatial Organization of Fish Diversity in a Species-rich Basin.” River Research and Applications 35(2): 188-196.

NRCS. 2011 Draft. NRCS/USACE Partnership Handbook: A Field Guide to Working Together Toward Shared Goals.

OEPA (Ohio Environmental Protection Agency).1987. Biological Criteria for the Protection of Aquatic Life, Volume II: User's Manual for Biological Field Assessment of Ohio surface waters. Columbus, OH: Ohio Environmental Protection Agency, Division of Water Quality Monitoring and Assessment.

Perlman, Howard. 2016. The USGS Water Science School, Surface Water, Watersheds. Available at: https://water.usgs.gov/edu/watershed.html [Accessed 20 Feb. 2018].

Pflieger, W. L. 1975. The Fishes of Missouri. Jefferson City, MO: Missouri Department of Conservation.

Pruitt, B.A., K. Jack Killgore, W. Todd Slack, L.E. Miranda, and C.A. Pruitt. 2017. "Watershed Assessment: A multi-scale approach using ecological modeling." In Proceedings of the 2017 Georgia Water Resources Conference, April 19-20, 2017. Athens, GA: University of Georgia.

Pruitt, B.A., S.J. Miller, C.H. Theiling, and J.C. Fischenich. 2012. The use of reference ecosystems as a basis for assessing restoration benefits. ERDC TN-EMRRPEBA-11. Vicksburg, MS: Engineer Research and Development Center.

Rykiel, E.J. Jr. 1996. “Testing Ecological Models: The Meaning of Validation.” Ecological Modelling 90: 229-244. 
Seaber, P.R., F.P. Kapinos, and G.L. Kapp. 1984. Hydrologic Unit Maps. USGS Water Supply Paper 2294. Washington, DC: US Geological Survey.

Smith, P. W. 1979. The Fishes of Illinois. Illinois State Natural History Survey. Urbana, IL: University of Illinois Press. 314 pp.

Smith, R.D., C.V. Klimas and B.A. Kleiss. A Watershed Assessment Tool for Evaluating Ecological Condition, Proposed Impacts, and Restoration Potential at Multiple Scales. ERDC TN-SWWRP-05-3. Vicksburg, MS: Engineer Research and Development Center.

Steedman, R. J. 1988. "Modification and Assessment of an Index of Biotic Integrity to Quantify Stream Quality in Southern Ontario.” Canadian Journal of Fisheries and Aquatic Sciences 45:492-501.

Stoddard, J., P. Larsen, C. P. Hawkins, R. Johnson, and R. Norris. 2006. “Setting Expectations for the Ecological Condition of Running Waters: The Concept of Reference Conditions." Ecological Applications 16:1267-1276

Tennessee Duck River Development Agency. 2011. Duck River Comprehensive Regional Water Supply Plan. Prepared by George Rest and Thomas Dumm. Nashville, TN: O’Brien \& Gere Engineers, Inc.

United States Department of Agriculture. 1998. Stream Visual Assessment Protocol. Technical Note 99-1. Washington, DC: USDA, Natural Resources Conservation Service, National Water and Climate Center.

USACE. 2012. Assuring quality of planning models - model certification/approval process, standard operating procedures. US Army Corps of Engineers, National Planning Centers of Expertise.

USACE. 2012. Cumberland and Duck River Basins: May 2010, Post Flood Technical Report. USACE, Nashville District.

USEPA. 2015. Tennessee Integrated Assessment of Watershed Health. Prepared by RTI International. Triangle Park, NC. www2.epa/gov/hwp

USGS Web Page. Watershed Definition. https://water.usgs.gov/edu/watershed.html

Williams, G. G. 1996. A watershed approach to assessing brook trout (Salvelinus fontinalis) distribution and ecological health in the Hiwassee watershed. Unpublished data report for cooperative agencies. Norris, TN: Tennessee Valley Authority, Hiwassee River Action Team. 


\section{Appendix: Stream Condition Index (SCI) Variable Definitions and Scores}

\begin{tabular}{|c|c|c|c|c|c|}
\hline Indices & $\begin{array}{l}\text { Definition and score } \\
\text { (high) }\end{array}$ & $\begin{array}{l}\text { Definition and score } \\
\text { (medium high) }\end{array}$ & $\begin{array}{l}\text { Definition and score } \\
\text { (medium) }\end{array}$ & $\begin{array}{l}\text { Definition and score } \\
\text { (medium low) }\end{array}$ & $\begin{array}{l}\text { Definition and score } \\
\text { (low) }\end{array}$ \\
\hline $\begin{array}{l}\text { Channel } \\
\text { Stability- } \\
\text { Cross- } \\
\text { section (CS) }\end{array}$ & $\begin{array}{l}\text { Natural channel in cross- } \\
\text { section relative to } \\
\text { reference conditions; No } \\
\text { evidence of channel } \\
\text { widening; Little or no } \\
\text { formation of mid-channel } \\
\text { bars. }\end{array}$ & $\begin{array}{l}\text { Evidence of past channel } \\
\text { alteration, but with } \\
\text { significant recovery of } \\
\text { channel and banks. } \\
\text { Moderate evidence of } \\
\text { channel widening and mid- } \\
\text { channel bar formation. }\end{array}$ & & $\begin{array}{l}\text { Altered channel; Excess } \\
\text { aggradation; Some } \\
\text { braided or anastomosed } \\
\text { channel. Severe } \\
\text { channel widening and } \\
\text { mid-channel bar } \\
\text { formation. }\end{array}$ & $\begin{array}{l}\text { Highly altered channel; } \\
\text { Excess aggradation; } \\
\text { Predominate braiding or } \\
\text { anastomosed channel. } \\
\text { Extreme channel } \\
\text { widening causing active } \\
\text { bank failure. }\end{array}$ \\
\hline CS Score $\rightarrow$ & 1.0 & 0.7 & & 0.3 & 0.1 \\
\hline $\begin{array}{l}\text { Hydrologic } \\
\text { Alteration } \\
(\mathrm{HA})\end{array}$ & $\begin{array}{l}\text { Natural channel; no } \\
\text { structures, dikes. No } \\
\text { evidence of down- cutting } \\
\text { or excessive lateral } \\
\text { cutting. No artificial } \\
\text { channel confinement. } \\
\text { Flood frequency onto } \\
\text { active floodplain every } \\
1.5 \text { to } 2 \text { years RI. }\end{array}$ & $\begin{array}{l}\text { Evidence of past channel } \\
\text { alteration, but with } \\
\text { significant recovery of } \\
\text { channel and banks. } \\
\text { Channel slightly incised. } \\
\text { Minimum artificial channel } \\
\text { confinement. Flood } \\
\text { frequency onto active } \\
\text { floodplain every } 3 \text { to } 5 \\
\text { years RI. }\end{array}$ & & $\begin{array}{l}\text { Moderately altered } \\
\text { channel; }<50 \% \text { of the } \\
\text { reach with riprap and/ } \\
\text { or channelization. } \\
\text { Channel deeply incised. } \\
\text { Flood frequency onto } \\
\text { active floodplain every } 6 \\
\text { to } 10 \text { years RI. }\end{array}$ & $\begin{array}{l}\text { Channel is actively } \\
\text { downcutting or } \\
\text { widening. }>50 \% \text { of the } \\
\text { reach with riprap or } \\
\text { channelization. Channel } \\
\text { severely incised. Flood } \\
\text { frequency onto active } \\
\text { floodplain }>10 \text { years RI. }\end{array}$ \\
\hline HA Score & 1.0 & 0.7 & & 0.3 & 0.1 \\
\hline $\begin{array}{l}\text { Riparian } \\
\text { Zone (RZ) }\end{array}$ & $\begin{array}{l}\text { Natural vegetation } \\
\text { extends at least two } \\
\text { active channel widths on } \\
\text { each side. }\end{array}$ & $\begin{array}{l}\text { Natural vegetation extends } \\
\text { one active channel width } \\
\text { on each side. } \\
\text { Or If less than one width, } \\
\text { covers entire flood plain. }\end{array}$ & $\begin{array}{l}\text { Natural vegetation } \\
\text { extends half of the } \\
\text { active channel width on } \\
\text { each side. }\end{array}$ & $\begin{array}{l}\text { Natural vegetation } \\
\text { extends a third of the } \\
\text { active channel width on } \\
\text { each side. or } \\
\text { Filtering function } \\
\text { moderately } \\
\text { compromised. }\end{array}$ & $\begin{array}{l}\text { Natural vegetation less } \\
\text { than a third of the active } \\
\text { channel width on each } \\
\text { side. or } \\
\text { Lack of regeneration. }\end{array}$ \\
\hline RZ Score $\rightarrow$ & 1.0 & 0.8 & 0.5 & 0.3 & 0.1 \\
\hline $\begin{array}{l}\text { Bank } \\
\text { Stability (BS) }\end{array}$ & $\begin{array}{l}\text { Banks are stable; banks } \\
\text { are low (at elevation of } \\
\text { active flood plain); } 33 \% \text { or } \\
\text { more of eroding surface } \\
\text { area of banks in outside } \\
\text { bends is protected by } \\
\text { roots that extend to the } \\
\text { base-flow elevation. }\end{array}$ & $\begin{array}{l}\text { Moderately stable; banks } \\
\text { are low (at elevation of } \\
\text { active flood plain); less } \\
\text { than } 33 \% \text { of eroding } \\
\text { surface area of banks in } \\
\text { outside bends is protected } \\
\text { by roots that extend to the } \\
\text { baseflow elevation. }\end{array}$ & & $\begin{array}{l}\text { Moderately unstable; } \\
\text { banks may be low, but } \\
\text { typically are high } \\
\text { (flooding occurs } 1 \text { year } \\
\text { out of } 5 \text { or less } \\
\text { frequently); out- side } \\
\text { bends are actively } \\
\text { eroding (overhanging } \\
\text { vegetation at top of } \\
\text { bank, some mature } \\
\text { trees falling into steam } \\
\text { annually, some slope } \\
\text { failures apparent). }\end{array}$ & $\begin{array}{l}\text { Unstable; banks may be } \\
\text { low, but typically are } \\
\text { high; some straight } \\
\text { reaches and inside } \\
\text { edges of bends are } \\
\text { actively eroding as well } \\
\text { as outside bends } \\
\text { (overhanging vegetation } \\
\text { at top of bare bank, } \\
\text { numerous mature trees } \\
\text { falling into stream } \\
\text { annually, numerous } \\
\text { slope failures apparent). }\end{array}$ \\
\hline BC Score $\rightarrow$ & 1.0 & 0.7 & & 0.3 & 0.1 \\
\hline $\begin{array}{l}\text { Water Color } \\
\text { (WC) }\end{array}$ & $\begin{array}{l}\text { Very clear, or clear but } \\
\text { tea-colored; objects } \\
\text { visible at depth } 3 \text { to } 6 \mathrm{ft} \\
\text { (less if slightly colored); } \\
\text { no oil sheen on surface; } \\
\text { no noticeable film on }\end{array}$ & $\begin{array}{l}\text { Occasionally cloudy, } \\
\text { especially after storm } \\
\text { event, but clears rapidly; } \\
\text { objects visible at depth } 1.5 \\
\text { to } 3 \mathrm{ft} \text {; may have slightly } \\
\text { green color; no oil sheen } \\
\text { on water surface. }\end{array}$ & & $\begin{array}{l}\text { Considerable cloudiness } \\
\text { most of the time; } \\
\text { objects visible to depth } \\
0.5 \text { to } 1.5 \mathrm{ft} \text {; slow } \\
\text { sections may appear } \\
\text { pea-green; bottom rocks } \\
\text { or submerged objects }\end{array}$ & $\begin{array}{l}\text { Very turbid or muddy } \\
\text { appearance most of the } \\
\text { time; objects visible to } \\
\text { depth < } 0.5 \mathrm{ft} \text {; slow } \\
\text { moving water may be } \\
\text { bright- green; other } \\
\text { obvious water } \\
\text { pollutants; floating algal }\end{array}$ \\
\hline
\end{tabular}




\begin{tabular}{|c|c|c|c|c|c|}
\hline Indices & $\begin{array}{l}\text { Definition and score } \\
\text { (high) }\end{array}$ & $\begin{array}{l}\text { Definition and score } \\
\text { (medium high) }\end{array}$ & $\begin{array}{l}\text { Definition and score } \\
\text { (medium) }\end{array}$ & $\begin{array}{l}\text { Definition and score } \\
\text { (medium low) }\end{array}$ & $\begin{array}{l}\text { Definition and score } \\
\text { (low) }\end{array}$ \\
\hline & $\begin{array}{l}\text { submerged objects or } \\
\text { rocks. }\end{array}$ & & & $\begin{array}{l}\text { covered with heavy } \\
\text { green or olive-green film. } \\
\text { or } \\
\text { Moderate odor of } \\
\text { ammonia or rotten eggs. }\end{array}$ & $\begin{array}{l}\text { mats, surface scum, } \\
\text { sheen or heavy coat of } \\
\text { foam on surface. } \\
\text { or } \\
\text { Strong odor of } \\
\text { chemicals, oil, sewage, } \\
\text { other pollutants. }\end{array}$ \\
\hline WC Score $\rightarrow$ & 1.0 & 0.7 & & 0.3 & 0.1 \\
\hline $\begin{array}{l}\text { Nutrient } \\
\text { Enrichment } \\
\text { (NE) }\end{array}$ & $\begin{array}{l}\text { Clear water along entire } \\
\text { reach; diverse aquatic } \\
\text { plant community includes } \\
\text { low quantities of many } \\
\text { species of macrophytes; } \\
\text { little algal growth present. }\end{array}$ & $\begin{array}{l}\text { Fairly clear or slightly } \\
\text { greenish water along entire } \\
\text { reach; moderate algal } \\
\text { growth on stream } \\
\text { substrates. }\end{array}$ & $\begin{array}{l}\text { Greenish water along } \\
\text { entire reach; } \\
\text { overabundance of lush } \\
\text { green macrophytes; } \\
\text { abundant algal growth, } \\
\text { especially during } \\
\text { warmer months. }\end{array}$ & $\begin{array}{l}\text { Pea green, gray, or } \\
\text { brown water along } \\
\text { entire reach; dense } \\
\text { stands of macrophytes } \\
\text { clog stream; severe } \\
\text { algal blooms create } \\
\text { thick algal mats in } \\
\text { stream. }\end{array}$ & \\
\hline NE Score $\rightarrow$ & 1.0 & 0.7 & 0.3 & 0.1 & \\
\hline $\begin{array}{l}\text { Fish Cover } \\
\text { (FC) }\end{array}$ & $>7$ covertypes available & 6 to 7 covertypes available & $\begin{array}{l}4 \text { to } 5 \text { cover types } \\
\text { available }\end{array}$ & $\begin{array}{l}2 \text { to } 3 \text { cover types } \\
\text { available }\end{array}$ & $\begin{array}{l}\text { None to } 1 \text { cover type } \\
\text { available }\end{array}$ \\
\hline FC Score $\rightarrow$ & 1.0 & 0.8 & 0.5 & 0.3 & 0.1 \\
\hline Pools (P) & $\begin{array}{l}\text { Deep and shallow pools } \\
\text { abundant; greater than } \\
30 \% \text { of the pool bottom is } \\
\text { obscure due to depth, or } \\
\text { the pools are at least } 5 \\
\text { feet deep. }\end{array}$ & $\begin{array}{l}\text { Pools present, but not } \\
\text { abundant; from } 10 \text { to } 30 \% \\
\text { of the pool bottom is } \\
\text { obscure due to depth, or } \\
\text { the pools are at least } 3 \text { feet } \\
\text { deep. }\end{array}$ & $\begin{array}{l}\text { Pools present, but } \\
\text { shallow; from } 5 \text { to } 10 \% \\
\text { of the pool bottom is } \\
\text { obscure due to depth, or } \\
\text { the pools are less than } \\
3 \text { feet deep. }\end{array}$ & $\begin{array}{l}\text { Pools absent, or the } \\
\text { entire bottom is } \\
\text { discernible. }\end{array}$ & \\
\hline P Score $\rightarrow$ & 1.0 & 0.7 & 0.3 & 0.1 & \\
\hline $\begin{array}{l}\text { Canopy } \\
\text { (CAN) }\end{array}$ & $\begin{array}{l}25 \text { to } 90 \% \text { of water } \\
\text { surface shaded; mixture } \\
\text { of conditions. }\end{array}$ & $\begin{array}{l}\text { > 90\% shaded; full canopy; } \\
\text { same shading condition } \\
\text { throughout the reach. }\end{array}$ & (intentionally blank) & $\begin{array}{l}<25 \% \text { water surface } \\
\text { shaded in reach. }\end{array}$ & \\
\hline $\begin{array}{l}\text { CAN Score } \\
\rightarrow\end{array}$ & 1.0 & 0.7 & & 0.1 & \\
\hline $\begin{array}{l}\text { Cattle } \\
\text { Access (CA) }\end{array}$ & $\begin{array}{l}\text { Evidence of livestock } \\
\text { access to riparian zone. }\end{array}$ & $\begin{array}{l}\text { Occasional manure in } \\
\text { stream or waste storage } \\
\text { structure located on the } \\
\text { flood plain. }\end{array}$ & $\begin{array}{l}\text { Extensive amount of } \\
\text { manure on banks or in } \\
\text { stream. or } \\
\text { Untreated human waste } \\
\text { discharge pipes present. }\end{array}$ & & \\
\hline $\begin{array}{l}\text { CAN Score } \\
\rightarrow\end{array}$ & 0.5 & 0.3 & 0.1 & & \\
\hline $\begin{array}{l}\text { Embeddedn } \\
\text { ess (EMB) }\end{array}$ & $\begin{array}{l}\text { Gravel or cobble particles } \\
\text { are }<20 \% \text { embedded. }\end{array}$ & $\begin{array}{l}\text { Gravel or cobble particles } \\
\text { are } 20 \text { to } 30 \% \text { embedded. }\end{array}$ & $\begin{array}{l}\text { Gravel or cobble } \\
\text { particles are } 30 \text { to } 40 \% \\
\text { embedded. }\end{array}$ & $\begin{array}{l}\text { Gravel or cobble } \\
\text { particles are }>40 \% \\
\text { embedded. }\end{array}$ & $\begin{array}{l}\text { Riffle is completely } \\
\text { embedded. }\end{array}$ \\
\hline $\begin{array}{l}\text { EMB Score } \\
\rightarrow\end{array}$ & 1.0 & 0.8 & 0.5 & 0.3 & 0.1 \\
\hline
\end{tabular}




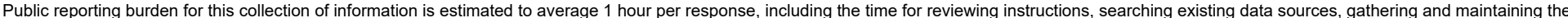

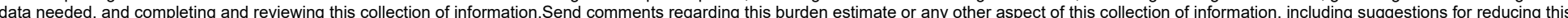

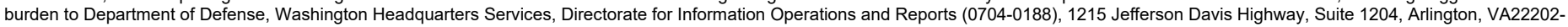

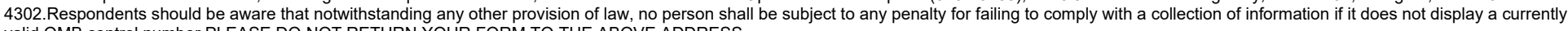
valid OMB control number.PLEASE DO NOT RETURN YOUR FORM TO THE ABOVE ADDRESS.
1. REPORT DATE (DD-MM-YYYY)
November 2020
2. REPORT TYPE
Final

\section{TITLE AND SUBTITLE}

Formulation of a Multi-Scale Watershed Ecological Model Using a Statistical Approach

6. AUTHOR(S)

Bruce A. Pruitt, K. Jack Killgore, W. Todd Slack, and Ramune Matuliauskaite

\section{DATES COVERED (From - To)}

5a. CONTRACT NUMBER

5b. GRANT NUMBER

5c. PROGRAM ELEMENT NUMBER

5d. PROJECT NUMBER

331898

5e. TASK NUMBER

5f. WORK UNIT NUMBER

8. PERFORMING ORGANIZATION REPORT NUMBER

ERDC/EL SR-20-6

10. SPONSOR/MONITOR'S ACRONYM(S)

11. SPONSOR/MONITOR'S REPORT NUMBER(S)

Nashville, TN 37203

12. DISTRIBUTION / AVAILABILITY STATEMENT

Approved for public release; distribution is unlimited.

\section{SUPPLEMENTARY NOTES}

\section{ABSTRACT}

The purpose of this special report is to provide a statistical stepwise process for formulation of ecological models for application at multiple scales using a stream condition index (SCI). Given the global variability of aquatic ecosystems, this guidance is for broad application and may re-quire modification to suit specific watersheds or stream reaches. However, the general statistical treatise provided herein applies across physiographies and at multiple scales. The Duck River Watershed Assessment in Tennessee was used, in part, to develop and test this multiscale, statistical approach; thus, it is considered a case example and referenced throughout this report. The findings of this study can be utilized to (1) prioritize watersheds for restoration, enhancement, and conservation; (2) plan and conduct site-specific, intensive ecosystem studies; and (3) assess ecosystem outcomes (that is, ecological lift) applicable to future with and without restoration actions including alternative, feasibility, and cost-benefit analyses and adaptive management.

15. SUBJECT TERMS

Watershed-Mathematical models Aquatic ecology

Streamflow

Duck River Watershed (Tenn.)

\begin{tabular}{|c|c|c|c|c|c|}
\hline \multicolumn{3}{|c|}{ 16. SECURITY CLASSIFICATION OF: } & $\begin{array}{l}\text { 17. LIMITATION } \\
\text { OF ABSTRACT }\end{array}$ & $\begin{array}{l}\text { 18. NUMBER } \\
\text { OF PAGES }\end{array}$ & $\begin{array}{c}\text { 19a. NAME OF RESPONSIBLE PERSON } \\
\text { Bruce Pruitt }\end{array}$ \\
\hline $\begin{array}{l}\text { a. REPORT } \\
\text { Unclassified }\end{array}$ & $\begin{array}{l}\text { b. ABSTRACT } \\
\text { Unclassified }\end{array}$ & $\begin{array}{l}\text { c. THIS PAGE } \\
\text { Unclassified }\end{array}$ & UU & 37 & $\begin{array}{l}\text { 19b. TELEPHONE NUMBER (in- } \\
\text { clude area code) } \\
\text { (706) } 248-1757\end{array}$ \\
\hline
\end{tabular}


